
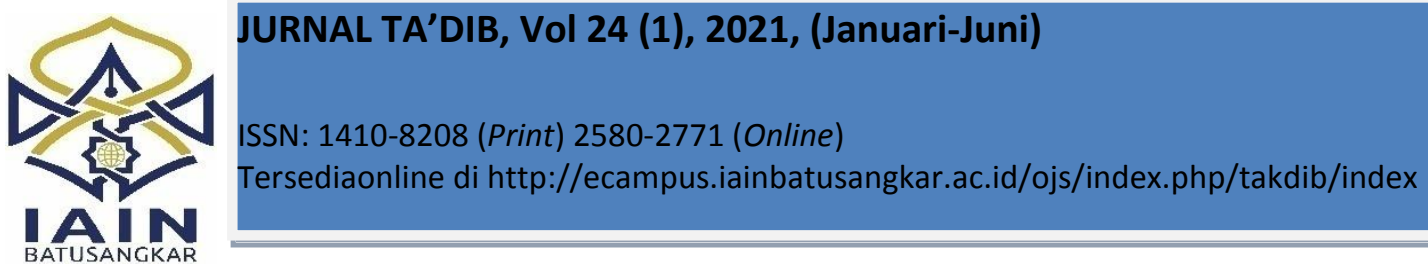

\title{
Developing Multimedia-Based English Listening Material for Islamic Senior High School
}

Received:30-03-2020; Revised:18-05-2021; Accepted:28-05-2021

\section{Yoki Irawan *)}

Institut Agama Islam Negeri Kerinci, Jambi, Indonesia

E-mail: yokiirawan@iainkerinci.ac.id

*) Corresponding Author

\begin{abstract}
This study aims at designing and developing multimedia-based English listening materials for the first year students of an Islamic Senior High School. The study was a Research and Development (R\&D) using ADDIE model. The respondents were 77 students and 4 English teachers of the firstyear students of MAN 1 Kerinci. The data of this research were obtained through observation checklist, interviews, questionnaires, validation sheet, and checklist of the product practicality. The findings of product validation and try-out show that the product is interesting and easy to use with minor revisions. Further, it facilitates the students to have self-learning listening. The final product of the study is an executable file $\left(^{*}\right.$ exe) attached on the CD. The result of the product validation, as well as the try-out, indicates that the material developed is categorized as "valid". The practicality of the material based on teachers and students' responses indicates that the material developed is "practical" to (Nunan, 1999) use in the classroom.
\end{abstract}

Abstrak: Penelitian ini bertujuan untuk merancang dan mengembangkan materi mendengarkan pada mata pelajaran bahasa Inggris berbasis multimedia untuk siswa kelas $X$ (sepuluh) Madrasah Aliyah Negeri. Penelitian ini merupakan Penelitian Pengembangan $(R \& D)$ yang menggunakan model ADDIE. Responden terdiri dari 77 siswa dan 4 guru bahasa Inggris siswa kelas sepuluh MAN 1 Kerinci. Data penelitian ini diperoleh melalui lembar observasi, pedoman wawancara, angket analisis kebutuhan, lembar validasi, dan angket kepraktisan produk. Hasil penelitian menunjukkan 1) Ada beberapa aspek kebutuhan yang harus diperhatikan dalam mengembangkan materi seperti input, bahasa, konten dan tugas dalam multimedia untuk meningkatkan pengetahuan dan keterampilan mendengarkan siswa. 2) Materi yang dikembangkan terdiri dari enam bagian yaitu: tujuan pembelajaran, kosa kata, pengayaan kosakata, kegiatan utama, fokus bahasa, dan refleksi. 3) Materi yang dikembangkan dikategorikan "Valid". 4) Tingkat kepraktisan materiberdasarkan respon guru dan siswa dikategorikan "Praktis".

Keywords: Multimedia-based, Listening, Material Development 


\section{INTRODUCTION}

$\mathrm{L}$ istening plays a significant role in English as a Foreign Language (EFL) classroom processes. It encourages their language skills through providing the aural for language learners (Mannion: 2014). When the learners understand the inputs in appropriate level, the learning process can begin (Rost: 2013) and the knowledge to start speaking can be built to maintain the current communication (Yildirim \& Yildirim: 2016). Therefore, teaching listening skills should be priorities in EFL classrooms.

Regardless of its significance, in EFL classroom, there are many problems faced by students namely input, context, listener, process, affect, and task problems (Namaziandost et al., 2019). Furthermore, related to the inputs in listening, teachers should provide students with different types of inputs such as lectures, radio news, films, TV plays, announcements, and interviews (Gilakjani \& Sabouri: 2016). The use of material is important to assist the learning process in listening class. Therefore, the students need an appropriate material in order to make the students be more active, interested and motivated in listening class.

Nowadays, teachers and students in Indonesia are challenged by the demand of integrating technology in ELT as an innovation in learning English including for Islamic Senior High Schools (MAN). One field of the listening researches related to the integration of the technology is developing listening materials by applying multimedia technologies. It is one of the main aspects and also trends to improve the development of foreign language teaching material around the world (Ni: 2017). Multimedia is not only used as aids of learning or media, but also can be as learning materials (Zaim: 2016). There are a lot of various types of multimedia that can be used by teachers for developing students' listening skills in teaching English listening, such as recorded TV programs available in the internet, and
YouTube. The teachers can download them in the forms of audios, videos, pictures, and animations and then adopt or adapt them. They can also create the learning materials or multimedia by themselves by using software. The software that can be used for developing multimedia for listening skills are exelearning (Zaim \& Refnaldi: 2016) and Adobe Animate CC 2019( Zaim et al.,: 2020)

Using multimedia-based materials in a teaching and learning process is assumed to give significant and positive effects in achieving learning goals. It improves students' motivation (Thamarana: 2016), triggers their learning interests, improves their listening ability as well as study efficiency which have outperformed the traditional education (Guo \& Jia: 2016), and gives positive impact on language learning since it allows learners to have an opportunity to interact, and to get feedback directly, improve learning autonomy, and get simulation of a real situation and experiences via video, audio and graphics( Gilakjani \& Ahmadi: 2011) cheaply and easily distributed and less time consuming for studying (Allesi \& Trollip: 2001). In addition, the development of the materials can be done if the textbooks or materials prepared by an institution do not meet the students' need in a current situation.

The teachers can also develop their own materials for their students which reflect the students' needs through adapting, adopting or developing the materials. Material development is aimed to provide source of language input conducted by writers, teachers or lecturers (Tomlinson, 2008). Therefore, by designing teachers own teaching material, it can be a better solution for the teachers since it enables them to create the teaching resources which appropriate in their teaching context and economical materials for students (Howard $\&$ Major, 2005). It is a way to provide the appropriate material based on the needs of students, grade, level, the school, and teachers. It also has positive results 
quantitatively and qualitatively in motivated students and improve the learning outcomes (Dodd et al., 2015).

In the Indonesian context, a number of studies found that developing multimediabased listening material will improve the students' motivation, interest, and fulfill the students' needs especially in encouraging them to be autonomous learners (Aziz, 2014; Nawangsasi, 2015; Rakhmawati et al., 2016; Syafi'i, 2016). Furthermore, the consideration in developing multimediabased English listening material was also arouse from the field problem. The current material was assumed not sufficient for the students. In the other words, it needed an improvement. In learning process, teachers usually used the printed book developed by the Ministry of Education entitled "Bahasa Inggris" without being accompanied by supporting materials such as audio, video, or animation.

Thus, there is a need to provide the appropriate material for the students to facilitate the development of their listening skills. Therefore, it is reasonable for this study to design and developing an appropriate material for English listening based on Multimedia. 8

\section{METHOD}

This research employed research and development (R\&D) design which aimed to develop a multimedia-based listening material for the first-year students of an Islamic High School. The researcher adapted ADDIE model (Branch, 2009). The respondents of this research were 77 first year students and 4 English teachers of MAN 1 Kerinci. The data were obtained through questionnaires of needs and situational analysis, the validation checklist, and the checklist of product practicality.

The procedure of this research consists a five phases namely: 1) Analyzing the needs and situation analysis through administering two sets of questionnaires to describe the students' wants and needs toward the listening materials; 2) Designing a prototype of the materials (course grid, flowchart and story-board); 3) Developing the prototype into the first draft by using the computer program namely Articulate Storyline 3. Then, validating the prototype by asking three experts' comments and suggestions for the material improvement; 4) Implementing the developed materials in the classroom through conducting some try-outs. The tryouts were administered twice in two different classes. To measure the practicality of the developed materials, at the end of the try-out session, the researcher gave the practicality checklist to the students and the teachers in order to find out their perception toward the practicality. Meanwhile, the evaluating process had been done in every stage of these phases.

\section{RESULTS AND DISCUSSION Analyzing}

Need analysis has been conducted in early phase of the development. It aims to gather the data related to the students' needs. The data were obtained by administering the questionnaires to the students and teachers. These questionnaires aimed to obtain the information about the students' and teachers' opinions on the targeted needs (lacks, wants) of English listening material. The needs analysis result can be seen as follows:

Table 1.The Result of Needs Analysis

\begin{tabular}{|c|c|}
\hline Aspect & Description \\
\hline Lack & $\begin{array}{l}\text { The first-year students of MAN } 1 \\
\text { Kerinci do not have any sufficient } \\
\text { materials, and so do the teachers. Such } \\
\text { kinds of English listening materials } \\
\text { that accommodate students' needs and } \\
\text { interest are presented by integrating } \\
\text { technology supporting English } \\
\text { listening teaching and learning } \\
\text { process. }\end{array}$ \\
\hline Want & $\begin{array}{l}\text { The first-year students of MAN } 1 \\
\text { Kerinci need multimedia-based } \\
\text { English listening materials that will be } \\
\text { used to encourage their self-access } \\
\text { (autonomous) in English listening } \\
\text { process. }\end{array}$ \\
\hline
\end{tabular}




$\begin{array}{ll}\text { Necessities } & \text { The first-year students of MAN } 1 \\ & \text { Kerinci in general need a better way to } \\ & \text { learn English listening. It should cover } \\ & \text { their capability and interest in using } \\ & \text { technology. In addition, the teachers } \\ & \text { also need to support the students' } \\ & \text { learning need and the demand of the } \\ & \text { 2013 curriculum in learning process. }\end{array}$

The needs for listening material are presented by following material design model namely: input, language, topic/content and task (Hutchinson \& Waters, 1987). First, in terms of input needed by the students, the students prefer to learn listening to any type of input called as multimedia. Therefore, the students' satisfaction and motivation are higher in courses that use multimedia material (Astleitner \& Wiesner, 2004). It implies that multimedia provides the appropriate input for the students in learning process. Second, in terms of the language needed by the students, there are some components and skills in the English language regarded as mostly significant, based on Permendikbud no 26 years 2016. The components are (1) the social functions, text structures, and language features of historical events, (2) the social functions, text structures, and language features of narrative texts related to the popular legends, (3) and the interpretations of social functions and language features of songs related to high school life.

Next, in terms of topic, it was found that the current topics provided in the textbook are less interesting. Unfortunately, the existing materials do not connect to the students' life experiences as individuals or Islamic students. It was in contrast with Alijani, et al. (2014) stating that they topics related to students' real life could increase their listening ability. It is not a surprise that the most important content for students is Islamic topics due to their background of study. So, there is no wonder that they are curious to learn more about them in the English language context. This is in line with
Rohmah's suggestion (2009) that the teaching materials in Islamic School should be related to its educational environment to assist students to master the English skill integratively.

Finally, in terms of task, it was found that the task is not interesting. Some experts suggest to use an authentic task such as suggested by Helgensen (2003). However, Nunan (2015) also provides a place for pedagogical or non-authentic tasks. A teacher can use non-authentic listening tasks in language classroom to check the students' comprehension but there should also be tasks that enable them to practice in class sorts of things that they need to do outside the classroom. By using non-authentic tasks related to the real-world ones, the teacher can evaluate the students' understanding of a listening text.

\section{Designing}

The Designing phase aims to design course grid, flowcharts, and story-boards, and to collect supplementary materials from the internet. In designing multimedia-based listening material, the results of the needs analysis phase are highly considered. As suggested the topics or contents are related to the Islamic contents, the language as imparted to the curriculum, and communicative tasks. In addition, these materials consist of a series of section related to teaching sequence. They are the statement of objectives, vocabulary builder and a quiz, preparation section, the main activities, language focus and reflection. This material was designed in four units. They are Unit 1: My Ramadan Experience (Recount Text), Unit 2: The Famous Leader (Biographical Recount), Unit 3: Tell Me an Interesting Story (Narrative Text), and Unit 4: entitled Thank You Allah (Songs).

In addition, the use of needs and curriculum analysis result as the basis for designing the material is considered as an effective way. It is in a line with Howard \&Major (2005) who state that an effective 
English language material should be related to the curriculum and students' teaching context. It aimed to provide the appropriate material related to students' life or needs, grade level, the schools' and teachers' needs. The design of the material can be seen in the following figure.

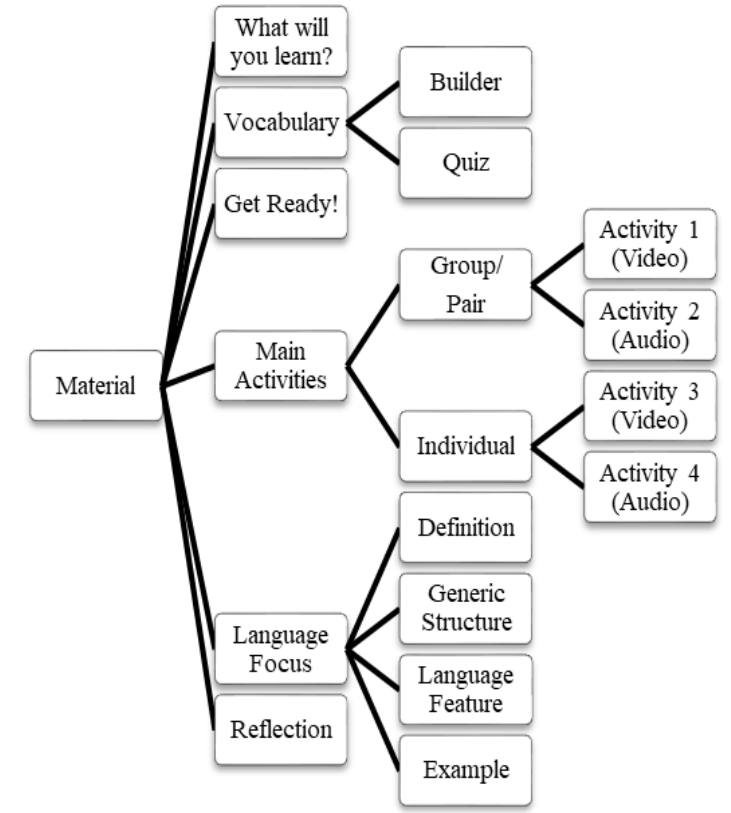

Figure 1: Design of the material

\section{Developing}

The development phase was to create story-board to become a real by using Articulate Story line 3 Software in order to combine all of the materials and the media elements that had been obtained into an application program. The result of this phase is a multimedia-based material in exe file attached in Compact Disk (CD). The front page of the product can be shown in figure 2 .

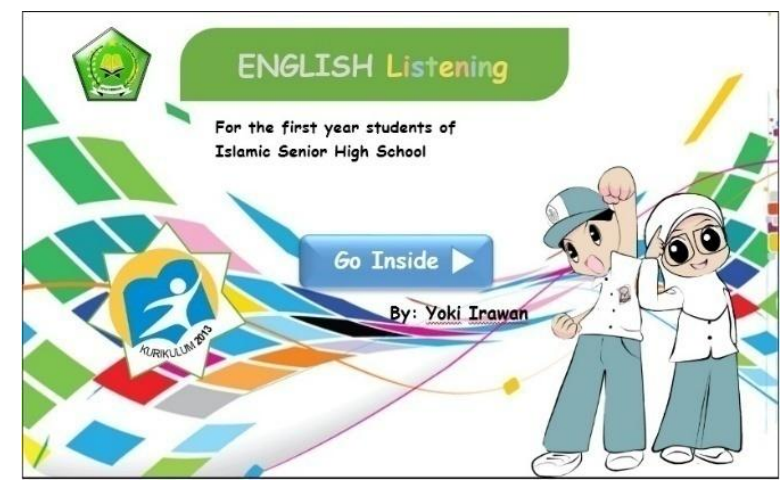

Figure 2: front page of the product
To finalize the product, the researcher conducted a formative evaluation. It aimed to measure the validity of the designed product and to obtain experts' comments and suggestions for the further revision. This validation stage consists of some aspects namely: Content, language, presentation, and multimedia. It was intended to evaluate the suitability of the listening material with the syllabus of 2013 Curriculum, language appropriateness, way of constructing the material presentation and to assess the usability of multimedia features in the material. The product was validated by three experts. The result of the validation process can be seen in the following table 2 :

Table 2.Experts'Validation Result

\begin{tabular}{ccc}
\hline Indicators & Score & $\begin{array}{c}\text { Category of } \\
\text { Validity }\end{array}$ \\
\hline Content & 3.26 & Very valid \\
Language & 3.17 & Valid \\
Presentation & 3.20 & Valid \\
Multimedia & 3.25 & Very valid \\
\hline Average & $\mathbf{3 . 2 2}$ & Valid \\
\hline
\end{tabular}

Table 2 shows that the meanscore from: (1) content is 3.26 which is categorized as very valid (2) language understanding is 3.17 which is categorized as valid (3) presentation is 3.20 which is categorized as valid (4) multimedia aspect is 3.25 which is categorized as very valid. Thus, based on the validation result, it was found that the designed material could be regarded as valid in that four components with total score was 3.22 .

Based on the validation result, the product meets the criteria of valid product as proposed by Depdiknas (2018). It fulfills the content (relevance) and construct (consistency) validity requirement and designed based on the students' needs (Nieveen \& Folmer, 2014). Furthermore, the multimedia aspects also achieved the valid and appropriate. Since the multimedia aspects such as screen design, interaction, feedback, navigation, color, text, graphic, 
animation, audio, and video (Sanjaya \& Sharma, 2005; Stemler, 1997)also meet the valid criteria.

In conclusion, the experts consider that in general the developed materials are recommended for listening activities in the classroom with minor revisions. The comments and suggestions from the experts are considered as the bases for the further revisions.

\section{Implementation}

The last procedure was conducting the product try-out. It was conducted to evaluate the level of usability or practicality of the product. There were 39 first-years students of MAN 1 Kerinci involved in this phase. After the product had been operated, and the students were asked to do listening exercises, the students and teachers were asked to give responses to some checklists. The results from data analysis of students' responses can be seen in the table 3 .

Table 3.The Students' Responses on Product

\begin{tabular}{ccc} 
& Practicality & \\
\hline Indicators & Score & $\begin{array}{l}\text { Category of } \\
\text { Practicality }\end{array}$ \\
\hline The ease of using & 3.22 & Practical \\
Time and cost & 3.29 & Very Practical \\
Functioning & 3.25 & Very Practical \\
\hline Average & $\mathbf{3 . 2 5}$ & Very Practical \\
\hline
\end{tabular}

Based on the table 3 above, it was found that the scores of: (1) the ease of using is 3.22 which is categorized as practical (2) time and the cost is 3.29 which is categorized as very practical (3) functioning is 3.25 which is categorized as very practical. Overall, the table 3 shows that the average score of the students' perception about the practicality of the developed material is 3.25 can be regarded as very practical material.

Furthermore, from the data analysis of teachers' practicality checklist, the teachers gave "practical" judgment. The result of data analysis of teachers' responses is displayed in the table 4.
Table 4. The Teachers' Responses on Product Practicality

\begin{tabular}{ccc}
\hline \multicolumn{3}{c}{ Practicality } \\
\hline The ease of using & 2.90 & $\begin{array}{c}\text { Category of } \\
\text { Practicality }\end{array}$ \\
Time and cost & 3.33 & Practical \\
Interpretation & 3.17 & Practical \\
Functioning & 3.38 & Very Practical \\
\hline Average & $\mathbf{3 . 1 9}$ & Practical \\
\hline
\end{tabular}

Based on table 4 above, overall, the finding shows that the average score of the teachers' responses on the practicality of the developed material is 3.19. It can be regarded as practical material.

This material is suitable to use for the first-year students of MAN 1 Kerinci in terms of the ease of using, time and cost, interpretation and responded by the teachers and the ease of using, time and cost, and function of the developed material from the students as the target users. In connection with this, the developed material can be categorized as the practical product. Since when end-users (teachers and students) consider that the developed product were usable and easy to use, it categorized that the product are practical (Nieveen \& Folmer, 2014).

\section{CONCLUSION}

The multimedia-based listening materials were designed based on need analysis result. It illustrates the mutual interrelation between the material itself and some aspects namely: goals, input, topics/contents, text genres, and tasks. The unity and the solidity of these aspects determine the success of the material. Furthermore, the developed material is suitable to be used in listening activities both inside and outside the classroom since as a self-access learning material, it could be operated individually and it meets the criteria of valid material practical to use in the English listening classroom. 


\section{REFERENCES}

Allesi, S. M., \& Trollip, S. R. (2001). Multimedia For Learning: methods and Development (Third). Allyn \& BAcon, Inc.

Astleitner, H., \& Wiesner, C. (2004). An Integrated Model of Multimedia Learning and Motivation. Journal of Educational Multimedia and Hypermedia, 13, 3-21. https://www.learntechlib.org/p/5049/

Aziz, M. S. A. (2014). Developing Listening Supplementary Materials for the Seventh Grade Students Based on Curriculum 2013. The 61st TEFLIN International Conference, 321-324. https://pdfs.semanticscholar.org/3f4a/d11 96ad5cfaf12febd627d0bb014af249bdb.p df

Branch, R. M. (2009). Instructional Design: The ADDIE Approach. Springer.

Depdiknas. (2018). Panduan Pengembangan Bahan Ajar. Direktorat Jenderal Pendidikan Dasar dan Menengah.

Dodd, A. R., Camacho, G. K., Morocho, E. L., Paredes, F. M., Zuniga, A., Pinza, E. I., Toro, L. V., Vargas, A. B., Benitez, C. D., \& Rogers, S. (2015). The Use of Supplementary Materials in English Foreign Language Classes in Ecuadorian Secondary Schools. English Language Teaching, $\quad$ 8(9), 187-195. https://doi.org/10.5539/elt.v8n9p187

Gilakjani, Abbas Pourhosein, \& Sabouri, N. B. (2016). Learners' Listening Comprehension Difficulties in English Language Learning: A Literature Review. English Language Teaching, 9(6), https://doi.org/10.5539/elt.v9n6p123

Gilakjani, Abbas Pourhossein, \& Ahmadi, M. R. (2011). A Study of Factors Affecting EFL Learners' English Listening Comprehension and the Strategies for Improvement. Journal of Language Teaching and Research, 2(5), 977-988.

https://doi.org/10.4304/jltr.2.5.977-988
Guo, T., \& Jia, Q. (2016). Research on the Impact of Multimedia Computer-based English Teaching in High School. International Journal of Emerging Technologies in Learning, 11(8), 33-39. https://doi.org/10.3991/ijet.v11i08.6042

Helgesen, M. (2003). Listening. In D. Nunan (Ed.), Practical English Language Teaching (First, pp. 1-353). McGrawHill.

Howard, J., \& Major, J. (2005). Guidelines for Designing Effective English Language Teaching Materials. 9th Conference of Pan Pacific Association of Applied Linguistics, 101-109. http://www.paaljapan.org/resources/proc eedings/PAAL9/pdf/Howard.pdf

Hutchinson, T., \& Waters, A. (1987). English for Specific Purposes. Cambridge University Press.

Namaziandost, E., Neisi, L., Mahdavirad, F., \& Nasri, M. (2019). The relationship between listening comprehension problems and strategy usage among advance EFL learners. Cogent Psychology, 6(1), 1-19. https://doi.org/10.1080/23311908.2019.1 691338

Nawangsasi, E. (2015). Developing Listening Materials for the Eighth-Grade Students of SMPN 14 Yogyakarta based on 2013 Curriculum. Universitas Negeri Yogyakarta.

Ni, D. (2017). Design and Research on English Listening Teaching Assisted by Computer Multimedia. IJET, 12(01), 32. https://doi.org/https://doi.org/10.3991/ijet .v12i01.6053

Nieveen, N., \& Folmer, E. (2014). Formative Evaluation in Educational Design Research. In T. Plomp \& N. Nieveen (Eds.), Educational Design Research (pp. 152-169). Netherlands Institute for Curriculum Development (SLO). https://doi.org/10.1007/978-1-46143185-5_11

Nunan, D. (1999). Second Language Teaching and Learning. Heinle \&Heinle. 
Nunan, D. (2015). Teaching English to Speakers of Other Languages. Routledge.

Rakhmawati, I., Iragiliati, E., \& Rachmajanti, S. (2016). Developing Supplementary Multimedia-Based Listening Materials for the Seventh Graders. Jurnal Pendidikan, 1(5), 940 947.

http://journal.um.ac.id/index.php/jptpp/ar ticle/view/6325

Rohmah, Z. (2009). EFL Materials In Madrasah Tsanawiyah: What Do They Really Need? TEFLIN Journal, 20, 104117.

http://journal.teflin.org/index.php/journal /article/view/85/80

Rost, M. (2013). Teaching and researching listening, second edition. In Teaching and Researching Listening, Second Edition. Pearson Education Limited. https://doi.org/10.4324/9781315833705

Sanjaya, M., \& Sharma, R. C. (2005). Interactive Multimedia in Education and Training. In Idea Group Publishing. Idea Group Publishing (an.

Stemler, L. K. (1997). Educational Characteristics of Multimedia: A Literature Review. Journal of Educational Multimedia and Hypermedia, 6(3-4), 339-359. https://pdfs.semanticscholar.org/ba51/fdf af6a295df45edfd7cba0ae4dff3cb8565.pd f?_ga $=2.200787181 .2986258 .157930287$ 0-2012462292.1579302870

Syafi'i, M. L. (2016). Developing Listening Materials For The Tenth Graders. JEELS, 3(1), 63-84. https://jurnal.iainkediri.ac.id/index.php/je els/article/view/174

Thamarana, S. (2016). Use of Multimedia Technologies in English Language Learning. International Journal of English Language Teaching, 4(8), 15-30.

Tomlinson, B. (2008). Language Acquisition and Language Learning Materials. In B. Tomlinson (Ed.), English Language Learning Materials (pp. 1-344). Continuum International Publishing Group.

Yildirim, S., \& Yildirim, Ö. (2016). The Importance of Listening in Language Learning and Listening Comprehension Problems Experienced by Language Learners: A Literature Review. Abant İzet Baysal Üniversitesi Ĕ̈itim Fakültesi Dergis, 16(4), 2094-2110.

Zaim, M., Refnaldi, R., \& Elfiona, E. (2020). Developing Mobile Based Authentic Listening Materials for Senior High School Students. Jurnal Ta'dib, 23(1), 110.

Zaim, Z. (2016). The Power of Multimedia To Enhance Learners' Language Skills in Multilingual Class. Proceedings of the Fourth International Seminar OnEnglish Language and Teaching (ISELT-4), 2229.

http://ejournal.unp.ac.id/index.php/selt/ar ticle/viewFile/6905/5439

Zaim, Z., \& Refnaldi, R. (2016). From Need Analysys t Multimedia Development: Using Exe-Learning in Developing Multimedia Based Listening Material. Proceedings of the 51st RELC International Conference on Teaching Literacies, 1-14. 